\title{
Komentarz do artykułu: „Leczenie antyagregacyjne u pacjentów z ostrym zespołem wieńcowym - zalecenia dla zespołów ratownictwa medycznego. Stanowisko ekspertów"
}

\author{
Prof. dr hab. n. med. Stefan Grajek \\ I Klinika Kardiologii, Uniwersytet im. K. Marcinkowskiego, Poznań
}

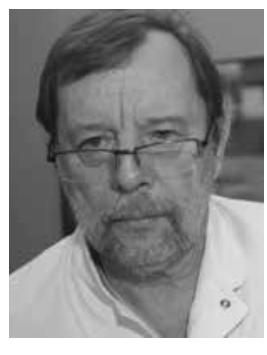

Podzielam opinie zawarte w aktualnych zaleceniach dla zespołów ratownictwa medycznego. Moje uwagi przede wszystkim dotyczą strategii postępowania u chorych z zawałem serca bez uniesienia odcinka ST (NSTEMI). W opracowanych wytycznych preferuje się stosowanie podwójnej terapii przeciwpłytkowej (DAPT) w fazie przedszpitalnej jedynie u pacjentów z grupy bardzo wysokiego ryzyka (koronarografia do 2 h). Chorzy ci stanowią jednak niewielki odsetek osób z NSTEMI. A co z pozostałymi pacjentami? Jak się wydaje, autorzy opracowania „niemo” założyli, że czas do wykonania koronarografii od 2 do 72 godzin (rekomendacje Europejskiego Towarzystwa Kardiologicznego [ESC]) przy stabilnym obrazie klinicznym pozwala zweryfikować poprawność rozpoznania, konieczność diagnostyki inwazyjnej i dokonanie wyboru optymalnej strategii terapeutycznej. Realizacja takiego postępowania sugeruje zatem powstrzymanie się od stosowania DAPT w fazie przedszpitalnej, kwestionując tym samym jej patofizjologiczne założenia. Takim zaleceniem kieruje przede wszystkim obawa przed spontanicznymi powikłaniami krwotocznymi — szczególnie przy niewłaściwym rozpoznaniu NSTEMI — i/lub w następstwie konieczności wykonania pilnego pomostowania aortalno-wieńcowego (CABG). Opinie kontestujące u chorych z NSTEMI zasadność stosowania DAPT $w$ fazie przedszpitalnej pojawiły się po opublikowaniu wyników badania ACCOAST [1], jednak w badaniu tym brak istotnej skuteczności klinicznej (efficacy) i wzrost powikłań krwotocznych (safety) dotyczył prasugrelu - nie zaś tikagreloru. W badaniu PLATO u pacjentów z NSTEMI tikagrelor w porównaniu z klopidogrelem istotnie redukował częstość występowania złożonego punktu końcowego (9,7\% vs. 11,8\%; RR 0,83; 0,71-0,96), a średni czas od podania leku do koronarografii wynosił ok. 4 godziny [2]. Dlaczego zatem nie stosować tikagreloru w szerszej populacji chorych z NSTEMI? Dlaczego mamy się ograniczać jedynie do grupy bardzo wysokiego ryzyka, tym bardziej że wg rejestru PL-ACS czas od rozpoznania NSTEMI do koronarografii wynosi ok. 12 godzin! [3]? Podważenie zaś patofizjologicznego uzasadnienia dla fazy przedszpitalnej u chorych z NSTEMI jest niesłuszne. Co prawda, STEMI od NSTEMI różni się formowaniem i lokalizacją obszaru martwicy, to jednak $1 / 3$ chorych z NSTEMI prezentuje martwicę pełnościenną, podobnie jak $1 / 3$ chorych z STEMI ma cechy rozsianej martwicy podwsierdziowej lub śródściennej [4, 5]. W obu typach zawału obserwuje się wzrost aktywności płytek. Ponadto w klasycznych już pracach wykazano całkowite zamknięcie naczynia odpowiedzialnego za zawał u 25-40\% pacjentów z NSTEMI [6]. Liczba pękniętych blaszek oraz ich morfologia w obrębie łożyska wieńcowego są w obu zawałach podobne, co więcej, w NSTEMI częściej występuje zakrzep „biały” (płytkowy) na zerodowanych blaszkach [7-9]. Dodatkowo rozległość zmian miażdżycowych w obrębie tętnic wieńcowych w NSTEMI jest znacznie większa. Z patofizjologicznego punktu widzenia intensywne leczenie przeciwpłytkowe jest wskazane w obu typach zawału niezależnie od obrazu klinicznego. Często podnoszonym argumentem uzasadniającym rezygnację ze stosowania tikagreloru w fazie przedszpitalnej jest krótki czas transportu i „nieostry” początek dolegliwości bólowych. Jakkolwiek średni czas transportu w Polsce jest krótki i wynosi ok. $30 \mathrm{~min}$, to o rozległości zawału, a tym samym jego obrazie klinicznym, decyduje całkowity czas niedokrwienia (total ischaemic time). Czas ten — od początku wystąpienia bólu - orientacyjnie można ustalić na podstawie wywiadu. Co ciekawe, krótki czas transportu nie jest argumentem za niestosowaniem DAPT w fazie przedszpitalnej w STEMI, obowiązuje bowiem obligatoryjna konieczność wykonania pierwotnej angioplastyki. Brak tak silnego imperatywu dla chorych z NSTEMI/UA, a także "lęk po ACCOAST" powoduje rzadsze stosowanie DAPT $w$ fazie przedszpitalnej. Obawa przed powikłaniami krwotocznymi jest jednak mało 
uzasadniona. W badaniu ATLANTIC tikagrelor podawany w fazie przedszpitalnej u chorych ze STEMI nie spowodował istotnego wzrostu powikłań krwotocznych w porównaniu z pacjentami leczonymi wewnątrzszpitalnie, chociaż ok. $35 \%$ osób w obu grupach otrzymało inhibitory glikoproteiny Ilb/IIla przed koronarografią [10]. Czy zatem obawa przed koniecznością wykonania pilnego CABG ogranicza stosowanie DAPT w fazie przedszpitalnej? Według rejestru AMI-PL tylko ok. 4\% chorych z NSTEMI jest operowanych w trakcie pobytu w szpitalu, a 1-1,5\% w ciągu pierwszych 24-48 godzin - są to więc odsetki znikome. Ponadto dane z rejestru SWEDEHEART wskazują, że chorych leczonych tikagrelorem można bez narażenia na duże powikłania operować już po 72 godzinach [11]. W cytowanych w aktualnie opracowanych rekomendacjach wytycznych ESC (NSTEMI 2015) zaleca się leczenie antagonistami P2Y12 niezależnie od wyboru strategii — inwazyjnej czy zachowawczej. Skuteczność tej ostatniej potwierdziły wyniki badania CURE [12], a obecnie PLATO [13]. Brak istotnych zmian w koronarografii również nie uzasadnia niechęci do stosowania DAPT w fazie przedszpitalnej. Wydaje się, że po badaniu ACCOAST zasadniczym czynnikiem ograniczającym stosowanie DAPT przed koronarografią jest niepewność dotycząca poprawności rozpoznania NSTEMI. Do zdiagnozowania zawału serca niezbędne są 2 spośród 3 wymaganych objawów: ból, zmiany niedokrwienne w zapisie elektrokardiograficznym i wzrost stężenia enzymów martwiczych. Dla zespołów pierwszego kontaktu brak możliwości oznaczenia troponin może stanowić pewien problem; dla szpitali bez pracowni hemodynamicznej informacja o podwyższonych stężeniach enzymów martwiczych powinna być bezwzględnym wskazaniem do podania tikagreloru na oddziale SOR lub w trakcie transportu przez zespół ratownictwa medycznego do najbliższej pracowni hemodynamicznej. Na zaproponowanym schemacie (przedstawionym w komentowanym artykule na rycinie 1) droga między szpitalami bez i z pracownią hemodynamiczną powinna być zaznaczona dodatkową strzałką. Czy zatem dla chorych z NSTEMI strategia „immediately after first medical contact" może zostać znacznie ograniczona? Należy powrócić do zapomnianej już skali TIMI RISK SCORE dla NSTEMI/UA, wprowadzając niewielkie zmiany interpretacyjne, przy niezmienionej liczbie punktów [14]. Spośród siedmiu ocenianych równoważnych cech (po 1 punkcie) tylko jedna (enzymy martwicze) jest dla zespołów wyjazdowych niemożliwa do oceny. Pozostałe sześć ustala się na podstawie wywiadu. Jak wykazali Budaj i wsp. [15], u chorych z NSTEMI wartości od 5 do 7 punktów stwierdza się u pacjentów z grupy wysokiego ryzyka, dla których złożony punkt końcowy (zgon sercowo-naczyniowy, zawał i udar) wystąpił w okresie 14 dni - u 20,7\% z grupy placebo i u 15,9\% leczonych klopidogrelem ( $p<0,04$, NNT $=21$ !). Wprowadzenie przez zespoły ratownictwa do rutynowej oceny (po odpowiednim szkoleniu) prostej skali ryzyka umocniłoby przekonanie o sensowności stosowania DAPT w fazie przedszpitalnej i znacznie zwiększyłoby liczbę chorych z NSTEMI korzystających z działania tikagreloru. Należy dążyć do upowszechnienia tej strategii poprzez wpisanie jej do dokumentów Ministerstwa Zdrowia regulujących zasady postępowania zespołów ratowniczych. Powtórzmy raz jeszcze - obawy po badaniu ACCOAST wzbudza prasugrel, nie zaś tikagrelor. U pacjentów z NSTEMI stosowanie tikagreloru w fazie przedszpitalnej jest w pełni uzasadnione i konieczne.

Konflikt interesów: honoraria za udział w komitecie doradczym AstraZeneca

\section{Piśmiennictwo}

1. Montelescot G, Bolognese L, Dudek D, et al. Pretreatment with prasugrel in non-ST segment elevation acute coronary syndromes. N Eng J Med. 2013; 369: 999-1010.

2. Cannon $\mathrm{CH}$. Harrington R. James S, et al. Comparison with clopidogrel in patients with a planed invasive strategy for acute coronary syndromes (PLATO): a randomised double-blind study. Lancet. 2010; 375: 283-293.

3. Gąsior M, Gierlotka M, Polonski L. PL-ACS. Prezentacja na Kongresie PTK Poznań 2016.

4. Savage R, Wagner G, Ideker R, et al. Correletion of postmortem anatomic findings with electrocardiographic changes in patients with myocardial infarction. Am J Cardiol. 1977; 55: 279-285.

5. Moon J, De Arenza D.,Elkington A et al. The pathologic basis of q-wave and non-q wave myocardial infarction. Am Coll Cardiol. 2004; 44: 554-560.

6. DeWood M, Stifter W, Simpson C, et al. Coronary arteriographic findings soon after non-Q myocardial infarction. N Eng J Med. 1986; 315: 417-423.

7. Kusama I, Hini K, Kosuge M, et al. Impact of plaque rupturę on infarct size ST-elevation anterior acute myocardial infarction. J Am Coll Cardiol. 2007; 50: 1230-1237.

8. Fuki K, Kobayashi Y, Mintz G, et al. Intravascular ultrasound assesement of ulcerated ruptured plaques. Circulation. 2003; 108: $2473-2478$.

9. Takano M, Inami S, Ishibashi F et al. Angioscopic follow-up of coronary ruptured plaques in non-culprit lesions. J Am Coll Cardiol. 2005; 45: 653-658.

10. Montalescot G, vant'Hof AW, Bolognese L, et al. Effect of pre-hospital ticagrelor during the first 24-h after primary percutaneous coronary intervention in patients with ST-elevation myocardial infarction. The ATLANIC- ${ }^{24}$ analysis. J Am Coll Cardiol Interv. 2016; 9: 646-656.

11. Hansson E, Jideus L, Aberg B et al. Coronary artery by-pass grafting-related bleeding complication in patients treated with ticagrelor or clopidogrel: a nationwide study. Eur Heart J. 2016; 37: 189-197.

12. CURE Trial Investigators. Effects of clopidogrel in addition to aspirin in patients with acute coronary syndromes without ST-segment elevation. N Eng J Med. 2001; 345: 494-502.

13. Wallentin L, Becker R, Budaj A, et al. Ticagrelor versus clopidogrel in patients with acute coronary syndromes N Eng J Med. 2009; 361: 1045-1057 (Supplementary Appendix).

14. Antman E, Cohen R, Bernik P, et al. The TIMI-risk score for unstable angina/non-ST elevation myocardial infarction: a method for prognostication and therapeutic decision making. JAMA. 2000; 284: 835-842.

15. Budaj A, Yusuf S, Mehta S, et al. Benefit of clopidogrel in patients with acute coronary syndromes without SI-segment elevation in various risk groups. Circulation. 2002; 106: 1622-1626. 